\title{
A NEW GENUS OF LINDSAEOID FERNS
}

\author{
K. U. KRAMER \\ (Botanical Museum $\mathcal{E}$ Herbarium Utrecht)
}

(received May 16th, 1957)

In revising the New World representatives of the genus Lindsaea, the author came across a fern specimen from Borneo preserved in the Rijksherbarium, Leiden, that did not seem to fit into any described genus. It had been described as Schizoloma stortii v. A. v. R., but in the author's opinion the genus Schizoloma Gaud., typified by Lindsaea ensifolia Sw., cannot be maintained (Kramer, 1957). Almost all species that in modern works have been left in it (e.g. HoLTTUM, 1954; Alston, 1956, as Schizolegnia) should be put back in Lindsaea. This, however, cannot be done with $S c h$. stortii, as this species possesses a peculiar combination of characters unlike anything found in Lindsaea. Its pinnae have a median main vein as in $L$. ensifolia, but are freeveined, and they have a large basal acroscopic auricle as in Isoloma, but are non-articulate. There is a remote resemblance to Lindsaea walkerae Hook., which may be its closest relative, as stipulated by van Alderwerelt van Rosenburgh in his original description; the natural place of that species too would perhaps be in a separate genus. Sch. stortii differs from it, a.o., by its pale axes and alternate auriculate pinnae. Because of its apparently rather isolated position, it seems indicated to create a separate genus for this fern.

Xyropteris Kramer, genus novum. - Ex affinitate Lindsaeae et Isolomae, exstat petiolo rhachideque pallida, pinnis alternis exarticulatis praeter auriculam basalim acroscopicam aequilateralibus, venis liberis, soris continuis. (Name derived from Greek $\xi$ vóv, razor-blade). Type and only species:

Xyropteris stortii (v. A. v. R.) Kramer, comb. nov.

Basionym: Schizoloma stortii v. A. v. R., Bull. Jard. Bot. Buitenz. 2me sér. 16:36 (1914); Malayan Ferns and Fern Allies Suppl. 1:214 (1916).

Schizolegnia stortii (v. A. v. R.) Alston, Bol. Soc. Broter. 2a sér. 30:24 (1956).

The original description, of which an almost verbal translation into English appeared two years later in the second of the above-named publications, is rather short and very incomplete, which is probably why this peculiar fern has never drawn the attention of other Pteridologists. Therefore a more complete description is given.

Rhizome apparently short-creeping (only short pieces present), stout, ca. $1 \frac{1}{4} \mathrm{~cm}$ in diam., solenostelic; scales lanceolate, acuminate, evenly golden-brown, non-clathrate, up to $5 \mathrm{~mm}$ long and $1.5 \mathrm{~mm}$ wide, with up to ca. 18 rows of cells at the base; similar scales 
persistent on the base of the petiole. Stipes stramineous to fawncoloured, terete at the base, upwards gradually channelled on the adaxial side, striate-canaliculate when dry, very stout, up to $11 / 2 \mathrm{~cm}$ in diam. at the base, $70 \mathrm{~cm}$ long, with a single vascular bundle. Rachis similar, adaxially with a narrow groove, its margins not interrupted at the insertion of the pinnae. Lamina up to ca. $11 / 2 \mathrm{~m}$ long, apparently broadly lanceolate, chartaceous to subcoriaceous, dark olivaceous on the adaxial side, paler on the abaxial side, simply

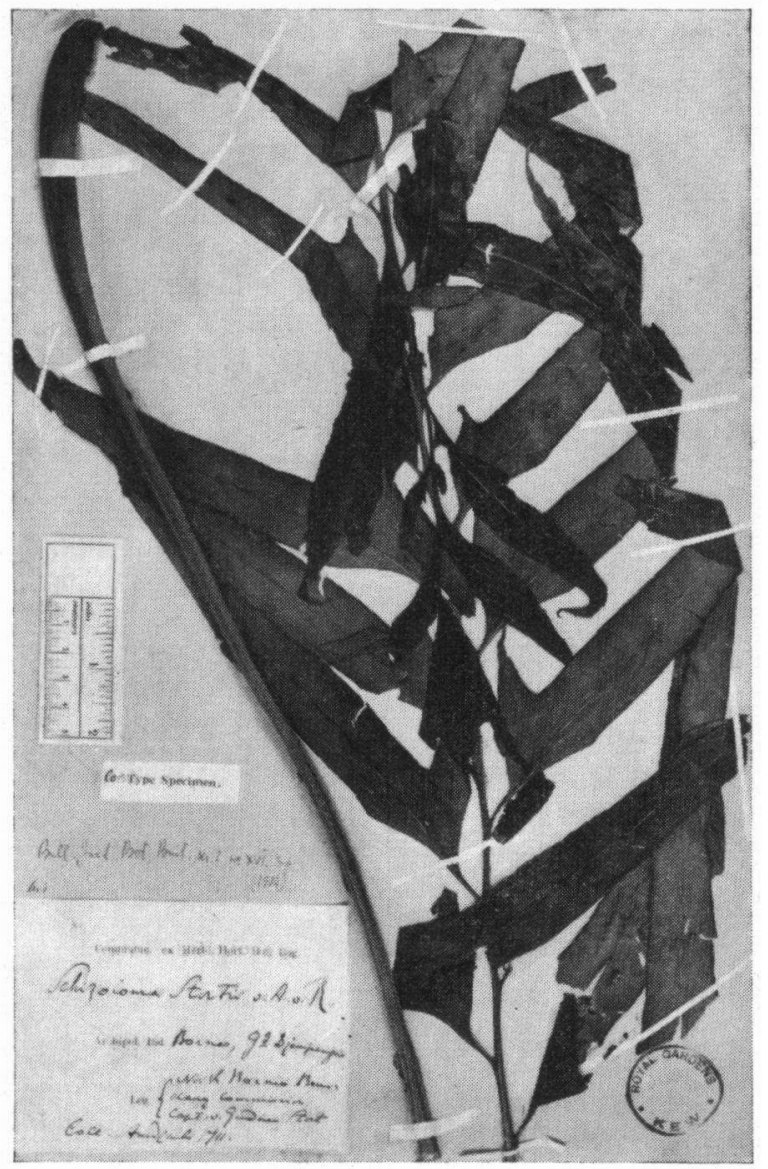

pinnate. Pinnae up to ca. 20 on each side, alternate, rather remote, the basal ones over $20 \mathrm{~cm}$ apart, the upper ones gradually closer, ascending under an angle of ca. $40^{\circ}$, provided with an adaxially sulcate stalk up to $1 \mathrm{~cm}$ long, and up to $30 \mathrm{~cm}$ long and $3 \mathrm{~cm}$ wide, narrowly lanceolate, the largest ones 7 to 10 times as long as wide, the upper ones relatively wider; lower pinnae not reduced, the upper 
ones gradually smaller, the uppermost ca. $8 \mathrm{~cm}$ long, subsessile; terminal segment distinct, trilobed (lost or damaged in all specimens). Base of pinnae long-cuneate, the leaf-tissue more strongly cut away on the basiscopic side, the acroscopic side at the base with a large acute auricle up to $7 \mathrm{~cm}$ long, either parallel with or somewhat divergent from the rachis; apex acuminate, coarsely serrate, the teeth ca. $1 \mathrm{~cm}$ apart; barren apex of auricle also serrate. Main vein median, raised on both sides, grooved on the adaxial side, stramineous to fawn-coloured; veins immersed but readily visible, very oblique, departing under an angle of ca. $10^{\circ}$ from the midrib but less oblique towards the margin, free except as united by the receptacle, mostly two or three times forked; the basal auricle also with a main vein. Sori continuous, absent from the extreme base and apex of the pinnae and the apex of the auricle. Indusium linear, opening outwardly, entire or wavy, brown, $0.25-0.30 \mathrm{~mm}$ wide, falling short of the margin by approximately its own width, more or less reflexed at full maturity. Sporangia ca. $280 \times 210 \mu$; annulus with 16-18 indurated cells which reach the insertion of the stalk; stomium strongly indurated, consisting of ca. 6 cells. Sporangia intermingled with filiform ca. $250 \mu$ long paraphyses of 5 to 6 cells with brown, apparently glandular apex. Spores medium brown, smooth, monolete, bean-shaped, $30 \times 50$ $35 \times 60 \mu$, probably 16 per sporangium.

Distribution: Only known from type-collection: Amdjah 711 (Captain van Genderen Stort's collector) from Mt. Djempanga, Borneo (B,O HoLOTYPE, 2 sheets; Isotypes in $\mathrm{K}, 2$ sheets, $\mathrm{L}$; fragment and sketch in C. Chr. in BM).

\section{REFERENCES}

Alston, A. H. G. 1956. New African ferns. Bol. Soc. Broter. 2a sér. 30:5. HoltTUM, R. E. 1954. A revised flora of Malaya. II. Ferns. Singapore.

KRAMER, K. U. 1957. A revision of the genus Lindsaea in the New World with notes on allied genera. Acta Bot. Neerl. $6(2): 97$. 